\title{
INSECT POLLINATORS' DIVERSITY OF RAPESEED (Brassica campestris var. toria) IN CHITWAN, NEPAL
}

\author{
R. Pudasaini ${ }^{1}$, R. B. Thapa ${ }^{1}$, N. K. Chaudhary ${ }^{1}$ and S. Tiwari ${ }^{2}$ \\ ${ }^{1}$ Institute of Agriculture and Animal Sciences, Tribhuvan University, Nepal. \\ ${ }^{2}$ Agriculture and Forestry University, Chitwan, Nepal
}

\begin{abstract}
The abundance and diversity of rapeseed insect flower visitors were assessed by using insect pan traps, sweep net and visual observations at different blooming stage of rapeseed at Jutpani VDC, Chitwan district, Nepal during 2012-013. The pollinator fauna of rapeseed included twenty one species from six different insect orders. Hymenopteran $(77.95 \%)$ species were the most abundant insects visiting rapeseed followed by Diptera $(12.23 \%)$ and Lepidoptera (3.49\%). Honeybees were the dominant group of pollinators and among honeybees, Apis mellifera L. was the most dominant one (36.34\%) followed by Apis florea F. (12.45\%), Apis cerana F. (11.14\%) and Apis dorsata F. (5.68\%). The higher abundance and diversity of pollinators were observed at 12:00 to 1:00 pm and the diversity was related to the crop blooming stage. Therefore, pollinator's friendly cultivation practices should be followed for conservation and management of insect pollinators for higher production and productivity of rapeseed crop under Chitwan condition.
\end{abstract}

Key words: Rapeseed, Insect pollinators, Diversity

\section{INTRODUCTION}

Rapeseed is cross-pollinated crop and requires sufficient pollinating agents for better pollination and seed production. The flowers of rapeseed are very attractive to bees. Honeybees visit rapeseed flowers for collection of both pollen and nectar, which in turn results into florets cross-pollination. Approximately $75 \%$ of major crops are animal pollinated which is an essential ecosystem service (Klein et al., 2007). It is prerequisite for pollen tube development and subsequent fertilization of ovules, leading to seed as well as fruit setting in flowering plants. Insect pollinators play crucial role in this process (Dhakal, 2003). Scientific evidence confirms that pollination improves the yield and quality of crops, such as fruits, vegetable seeds, spices, oilseeds and forage crops (Partap and Partap, 1997; Thapa, 2006; Singh et al., 2000, Singh, 2008). For better pollination and productivity of crops, proper methods of utilizing pollinators are important, which are specific for honeybees, other bees and insects (Sihag, 2000).

It has been reported that after heavy use of chemical pesticides all domesticated bees were wiped out in Ilam and Nuwakot districts, furthermore many colonies were destroyed in Chitwan district, Nepal (Sharma, 1994; Thapa, 1994). Similarly, farmers have realized that high level of pesticide application causes negative impact on insect pollinators and pollinator's deficit is a serious problem in Chitwan (FAO, 2011). Low pollinators abundance and diversity has also started appearing in different part of the world (Kasina et al., 2009). Due to continuous use of pesticides and declining of natural habitat, insect pollinators are decreasing rapidly (Richards, 2001). Knowledge of the specific pollinators of rapeseed crop is limited in the context of Nepal although its pollination requirements 
have been studied in other countries. Therefore, this study was carried out to collect and identify the insect pollinators of rapeseed crop.

\section{MATERIALS AND METHODS}

An experiment was conducted at Jutpani VDC, Chitwan district of Nepal during October 2012 to February 2013. The plot size was $3 \mathrm{~m}$ x $5 \mathrm{~m}\left(15 \mathrm{~m}^{2}\right)$ separated by $0.5 \mathrm{~m}$ distance between plots and $1 \mathrm{~m}$ between replications. Rapeseed variety Pragati was sown on $3^{\text {rd }}$ November, 2012 following all the recommended agronomical practices (Singh et al., 2010; Basnet, 2005). The fertilizers were applied@15 ton/ha FYM, 60:60:40 kg NPK/ha and Sulphur@30 kg/ha. Full FYM, half nitrogen, full phosphorus and potassium were applied as a basal dose and remaining nitrogen as top dressing at 21 days after sowing (DAS). The seeds were sown at 3-4 cm depth of soil @ $6 \mathrm{~kg} / \mathrm{ha}$ in well prepared field maintaining $20 \mathrm{~cm}$ x $5 \mathrm{~cm}$ spacing between row to row and plant to plant, respectively. Two intercultural operations were done to remove weeds during early vegetative growth period at 21 DAS and 35 DAS.

To know the presence of pollinators' diversity pan trap, sweep net and visual observations were done at different blooming stage as $10 \%$ crop blooming, peak blooming and $10 \%$ flowers remaining stage of rapeseed. Three different colors of pan traps, namely yellow, blue and white were placed in three meter distance to each other in alternate way with respect to colors in rapeseed field. After twenty four hours, these pan traps were removed and insect trapped were pinned and identified with the help of dichotomous key. Similarly, sweep net and visual observation were also conducted at different time of the day as 9:00 am, 12:00 noon, 2:00 pm and 4:00 pm in same crop blooming stage. Representatives of the insects species sampled were sorted out, pinned and identified. The total numbers of each of the identified insect species was recorded.

\section{RESULTS AND DISCUSSION}

Different pollinators recorded in rapeseed flower are presented on Table 1 and Figure 1. The pollinator fauna of rapeseed included twenty one species from six different insect orders. Hymenopteran (77.95\%) species were the most abundant insects visiting rapeseed followed by Diptera (12.23\%), Lepidoptera (3.49\%), Coleoptera (2.18\%), Heteroptera (2.18\%) and the lowest Orthoptera (1.97\%), respectively. Seven different Hymenopteran families were recorded and among them Apidae was dominant family. Honeybees were the abundant group of pollinators. Among honeybees, Apis mellifera L. was the most dominant one (36.34\%); followed by Apis florea F. (12.45\%), Apis cerana F. (11.14\%) and Apis dorsata F. (5.68\%). Similarly, Andrena sp. (3.71\%) and Megachilus sp. (0.66\%) were also recorded. The other pollinators constituted 22.05\%, which included Diptera, Lepidoptera, Orthoptera, Coleoptera and Heteroptera. Among the Dipterans, Syrphid fly (5.9\%) were important flower visitors followed by housefly (3.93\%). The higher abundance and diversity of pollinators was observed at 12:00 to 1:00 pm and the diversity was related to the crop blooming stage. 
Table 1. Relative abundance of insect pollinators occurring on rapeseed flowers in Jutpani VDC, 2012/013

\begin{tabular}{|c|c|c|c|c|}
\hline SN & Common Name & Scientific Name & Order: Family & Relative abundance (\%) \\
\hline 1 & European bee & Apis mellifera $\mathrm{L}$. & Hymenoptera: Apidae & 36.24 \\
\hline 2 & Little bee & Apis florea $\mathrm{F}$. & Hymenoptera: Apidae & 12.45 \\
\hline 3 & Asian bee & Apis cerana $\mathrm{F}$ & Hymenoptera: Apidae & 11.14 \\
\hline 4 & Rock bee & Apis dorsata $\mathrm{F}$. & Hymenoptera: Apidae & 5.68 \\
\hline 5 & Bee & Andrena sp. & Hymenoptera: Andrenidae & 3.71 \\
\hline 6 & Wasp & Polistes sp. & Hymenoptera: Eumonidae & 2.18 \\
\hline 7 & Wasp & Vespa sp. & Hymenoptera: Vespidate & 1.10 \\
\hline 8 & Bee & Megachilus sp. & Hymenoptera: Mechachilidae & 0.66 \\
\hline 8 & Ant & & Hymenoptera: Formicidae & 4.37 \\
\hline 9 & Tabanid fly & Tabanus spp. & Diptera & 2.40 \\
\hline 10 & Syrphid Fly & Syrphus sp. & Diptera: Syrphidae & 5.90 \\
\hline 11 & Housefly & Musca domestica L. & Diptera: Muscidae & 3.93 \\
\hline 12 & Red pumpkin beetle & Aulacophora foveicollis & Coleoptera: Chrysomelidae & 1.75 \\
\hline 13 & Black Beetle & & Coleoptera & 0.44 \\
\hline 14 & Short horned Grass hopper & Oxya spp. & Orthoptera: Acriidae & 1.53 \\
\hline 15 & Long horned Grass hopper & & Orthoptera: Tetigonidae & 0.44 \\
\hline 16 & Cabbage butterfly & $\begin{array}{l}\text { Pieris brassica } \\
\text { nepalensis Doubleday }\end{array}$ & Lepidoptera: Peiridae & 1.97 \\
\hline 17 & Tiger moth & Nyctemers streama & Lepidoptera & 0.44 \\
\hline 18 & Cowpea pod borer & Lampides boeticus & Lepidoptera: Lycaenidae & 0.87 \\
\hline 19 & Rice skipper & Pelopidas spp. & Lepidoptera: Hesperiidae & 0.22 \\
\hline 20 & Green bug & Nezara viridula (L.) & Heteroptera: Pentatomidae & 2.18 \\
\hline
\end{tabular}

The flowers of rapeseed are very attractive to bees and honeybees visit rapeseed flowers for collection of both pollen and nectar. Higher number of Apis mellifera L. colonies kept by farmers resulted in their higher population during rapeseed flowering period. Similar results on insect visitors were reported by Dhakal (2003) on rapeseed field. Atmowidi et al. (2007) listed four orders of insect family, namely: Hymenoptera, Lepidoptera, Diptera and Coleoptera occurring in rapeseed field. Similarly, Rader (2010) observed five insect orders, namely: Hymenoptera, Lepidoptera, Diptera, Coleoptera and Hemiptera in rapeseed field. Present finding reports the most dominant honeybee species Apis mellifera L. but Mishra et al. (1988) argued that among many insect flower visitors, Apis cerana $\mathrm{F}$. indica was the most common pollinating species in India. This was due to higher number of Apis mellifera L. colonies near the experimental field in the present study. Viraktmath et al. (2001) recorded 29 insect species, of which 15 species belonged to Hymenoptera, 8 species to Diptera and 6 species to Lepidoptera from sunflower, sesame, mustard and niger flowers, respectively. Similarly, the pollinator fauna of niger included 14 species, as honeybees are the dominant group of pollinators and among honey bees, Apis dorsata proved to be the most dominant one (Dhurve, 2008). 


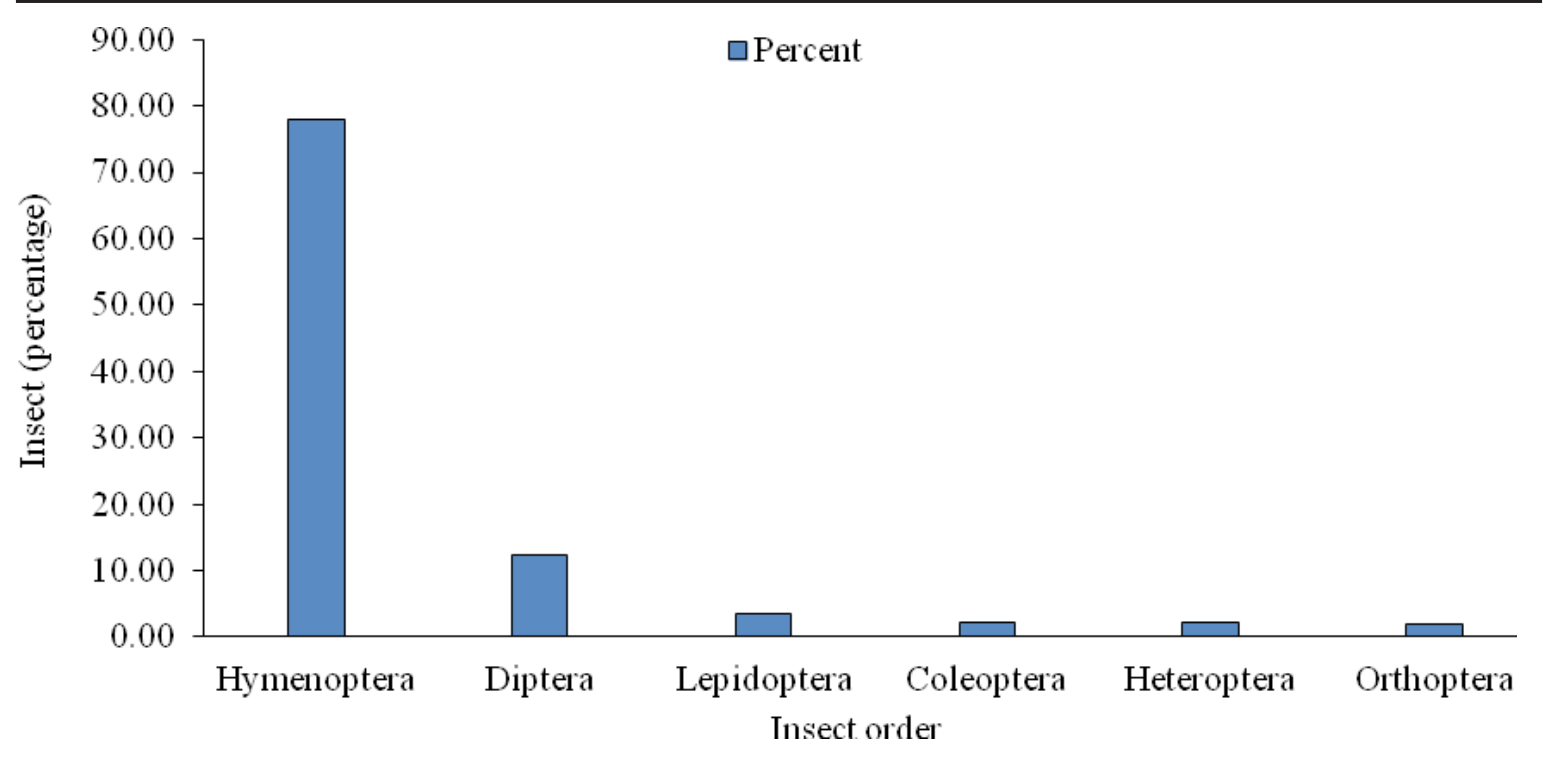

Figure 1. Relative abundance of insect pollinators during rapeseed flowering in Jutpani VDC Chitwan, 2012

\section{CONCLUSIONS}

The above study concludes that the honeybees are the major insect pollinators of rapeseed and among honeybee Apis mellifera $\mathrm{L}$, is the major pollinators. Among pollinators, bees are the most diverse groups of insects. The higher abundance and diversity of pollinators observed at 12:00 to $1: 00 \mathrm{pm}$ and the diversity was related to the crop blooming stage. Hence, pollinator's friendly cultivation practices should be practiced for conservation and management of insect pollinators for higher production and productivity of rapeseed crop under Chitwan condition.

\section{REFERENCES CITED}

Atmowidi, T. D., S. Buchori, B. Manuwoto and P. Hidayat. 2007. Diversity of pollinator insects in relation to seed set of mustard (Brassica rapa L.). HAYATI Journal of Biosciences 14(4): 155161.

Basnet, K. B. 2005. Effect of different combinations of nutrient sources and weeding practice on the physiological characters of rapeseed in humid subtropical condition of Chitwan. Journal Institute of Agriculture and Animal Science 26: 51-55.

Dhakal, G. C. 2003. A comparative study of Apis cerana F. and Apis mellifera L. on pollination of Brassica campestris Var. toria and Fagopyrum esculentum M. at Rampur, Chitwan. M. Sc. Thesis, Department of Entomology, TU. IAAS, Rampur, Chitwan, Nepal.

Dhurve, S. S. 2008. Impact of honeybee pollination on seed production of niger. M. S. Thesis, University of Agricultural Sciences, Dharwad. India. 
FAO. 2011. Protocol to detect and assess pollination deficits in crops: A handbook for its use. Food and Agriculture Organization of the United Nations, Rome, Italy.

Kasina, M., M. Kraemer, C. Martius and D. Wittmann. 2009. Diversity and activity density of bees visiting crop flowers in Kakamega, western Kenya. Journal of Apicultural Research 48 (2): 134-139.

Klein, A. M., B. E. Vaissiere, J. H. Cane, I. Steffan-Dewenter, S. A. Cunningham, C. Kremen, and T. Tscharntke. 2007. Importance of pollinators in changing landscapes for world crops. Proceedings of the Royal Society of London B 274: 303-313.

Mishra, R. C. and J. K. Gupta. 1988. The effect of mode of pollination on yield and oil potential of Brassica campestris L. var. sarson with observation on insect pollinators. Journal of Apiculture Research 27 (3): 186-189.

Partap, U. and T. Partap. 1997. Managed crop pollination. The missing dimension of mountain crop productivity. Discussion paper series No. MFS 97/1, ICIMOD, Kathmandu, Nepal.

Rader, R. 2010. The provision of pollination services to agro-ecosystems by a diverse assemblage of wild, unmanaged insect taxa. PhD Thesis, James Cook University. Available on :http://eprints. jcu.edu.au/21912.

Richards, A. J. 2001. Does low biodiversity result from modern agricultural practices affect crop pollination and yield? Annual Botany 88: 165-172.

Sharma, K. C. 1994. Current experiences and practices in pesticide use in the Bagmati zone. ADPI series \#9. ICIMOD, Kathmandu, Nepal.

Sihag, R. C. 2000. Management of bees for pollination. In: M. Matska, L. R. Verma, S. Wongsiri, K. K. Shrestha and U. Partap (eds.) Asian Bees and Beekeeping-Progress of Research and Development. Proceeding of Fourth Asian Apicultural Association International Conference, Kathmandu. March 23-28, 1998. Oxford and IBH Publication Company Private Limited, India. pp. 163-165.

Singh C., P. Singh and R. Singh. 2010. Modern techniques of raising field crops. 2nd Edition. Oxford and IBH Publishing Company Private Limited, New Delhi, India.

Singh, M. M. 2008. Foraging behavior of the Himalayan honeybee (Apis cerana F.) on flowers of Fagopyrum esculentum M. and its impact on grain quality and yield. Ecoprint 15: 37-46.

Singh, M. P., K. I. Singh and C. S. Devi. 2000. Role of Apis cerana himalaya pollination on yield and quality of rapeseed and sunflower crop. In: M. Matska, L. R. Verma, S. Wongsiri, K. K. Shrestha and U. Partap (eds.). Asian Bees and Beekeeping-Progress of Research and Development. Proceeding of Fourth Asian Apicultural Association International Conference, Kathmandu. March 23-28, 1998. Oxford and IBH Publication Company Private Limited, India. pp. 186-189.

Thapa, R. B. 1994. Environmental impacts from Nepal's use of chemical pesticides. Consultancy report submitted to WWF Nepal. APROSC, Kathmandu, Nepal. 
Thapa, R. B. 2006. Honeybee and other insect pollinators of cultivated plants: A review. Journal of Institute of Agriculture and Animal Science 27:1-23.

Viraktmath, S.A., B. Patil, S. Murasing and G. S. Guruprasad. 2001. Relative abundance of pollinator fauna of cross-pollinated oilseed crops at Dharwad in Karnataka (India). Indian Bee Journal 63 (3-4): 64-67. 